\title{
Profitability Determinants of Manufacturing Firms in Indonesia
}

\begin{abstract}
Submitted 10/01/20, $1^{\text {st }}$ revision 18/02/20, $2^{\text {nd }}$ revision 13/03/20, accepted 04/04/30
\section{Didik Susilo $^{1}$, Sugeng Wahyudi ${ }^{2}$, Irene Rini Demi Pangestuti ${ }^{3}$}

Abstract:

Purpose: The purpose of this study is to explore the most significant profitability determinants of the manufacturing companies in Indonesia.

Design/Methodology/Approach: Several independent variables examined for their influence on profitability were working capital, firm size, firm growth, capital structure, and non-debt tax shields. The sample of this study were manufacturing firms listed on the Indonesia Stock Exchange from 2010 to 2017. The number of samples were 350 manufacturing companies.

Findings: The results of this study indicate that working capital, firm size and firm growth were positively related to profitability. Meanwhile, capital structure and non-debt tax shield did not affect profitability. The findings of this study were consistent with the pecking order theory and the financial agency theory.

Practical implications: This study implies that managers need to adjust their investment needs with the profitability that has been achieved and the total assets of the company, and to maximize the value of the company by managing current assets so that the rate of the return on marginal investment is equal to or greater than the cost of capital used to finance the current assets. Furthermore, financial managers must be able to determine essential investment objectives by maximizing the use of assets and fixed assets which are expected to make the company to enjoy the sales growth in the future.

Originality/Value: Although this study organically builds upon recent studies about the firms' profitability, it conducted in the new administrative setting in Indonesia, which is the Widodo's administration. Widodo's administration supports the manufacturing industry to be able to compete globally.
\end{abstract}

Keywords: Profitability, manufacturing company, working capital, firm size, firm growth.

JEL Codes: G30, G32.

Paper Type: Research Paper.

\footnotetext{
${ }^{1}$ Universitas Diponegoro, Doctoral Program in Economics, didiks3undip@gmail.com

${ }^{2}$ Universitas Diponegoro, Faculty of Economics and Business, Department of Management, sug_w@yahoo.com

${ }^{3}$ Universitas Diponegoro, Faculty of Economics and Business, Department of Management, irenerinidp@live.undip.ac.id
} 


\section{Introduction}

Profitability is a very important concept in the financial literature, especially since Miller and Modigliani (1961) presented the theory of dividend irrelevance, which states that company performance is only determined by its basic ability to generate profits and face business risks. Various studies have been conducted to prove that profitability is a determinant of the company performance (including the research results by Aqil, Ahmed, Vveinhardt, and Streimikiene (2019); Battaglia and Gallo (2015); Handriani and Robiyanto (2018a; 2018b; 2019). Topics on profitability determinants of manufacturing companies in Indonesia have gained much attention in recent years in the context of the rapidly changing framework of the Indonesian government. Indonesia has a road map and strategy to deal with the entry of the industrial era 4.0 officially. This roadmap was launched during Indonesian Joko Widodo's administration through the ministry of industry, committing to build a manufacturing industry that is globally competitive through accelerating the implementation of industry 4.0.

According to Handriani and Robiyanto (2018b), profitability is one of the most important goals of financial management besides maximizing the owner's wealth. Profitability is a very important performance determinant. An unprofitable business is impossible to survive. Conversely, highly profitable businesses have the ability to reward their owners with large profits on their investments. Therefore, the ultimate goal of a business entity is to gain a profit to ensure its business continuity under the prevailing market conditions.

Borio, Gambacorta and Hofmann (2017) defined profitability as a business capability, interpreting profit over a certain period. It is important to examine the profitability determinants in order to understand how companies finance their operations. Financial benefits are realized when the amount of income earned from business activities exceeds the costs and taxes are needed to maintain the corporate activities. Profitability is able to describe the company's performance in terms of the profits it receives from investments by shareholders or the amount of capital used in the business or in relation to sales activities. Considering the main purpose of investing which is for profit, therefore the profits deriving from a business are used to measure the success of the investment.

The purpose of this study is to explore the most significant profitability determinants of the manufacturing companies in Indonesia. Several independent variables examined for their influence on profitability were working capital, firm size, firm growth, capital structure, and non-debt tax shields.

\section{Hypothesis Development}

Capital structure decisions are very important for every business organization. This is because there is a need to maximize profitability and there will be an impact of the 
decision on the company's ability to win in its competitive environment. The capital structure of a company is actually a mixture of various different funding sources. In general, a company can choose among many alternative capital structures. The financial managers may choose to use a large amount of debt to obtain profitability.

The trade-off theory has been developed in explaining the company's capital structure to profitability. The greater the profitability obtained by the company, the greater the debt support needed to generate the company's investment activities. Although it is very attractive, the researchers in financial management have not found an optimal capital structure, the best one that can be achieved by the company to obtain maximum profitability (Rupeika-Apoga et al., 2018: Thalassinos et al., 2015b). Researches on capital structure and profitability had been carried out in developed countries and found a positive relationship between the capital structure to profitability (Balios, Daskalakis, Eriotis, Vasiliou and McMillan, 2016; Maneerattanarungrot and Donkwa, 2018; Mateev, Poutziouris, and Ivanov, 2013; Sutomo, Wahyudi, Rini Demi Pangestuti, and Muharam, 2019). Similar studies in Indonesia also show the same evidence as that conducted by Hasbi (2015), Bratamanggala (2018) and Utama and Sulistika (2015). Therefore, the first hypothesis that can be formulated is as follows:

\section{H1: Capital structure has a positive effect on profitability.}

Basically, every company has the same goal which is aiming for profit maximization. To achieve this goal, the company management is required to be responsible for internal problems that arise from within the company itself, such as management problems. The management of each company includes many options one of which is the financial management which includes the management of working capital. Working capital is defined as funds used to finance the company's daily operations. Every kind of management may include cash, banking, receivables, inventories and income management that is still acceptable (Wahyudi, Goklas, Rita, Hersugondo and Laksana, 2019). The availability of working capital funds needed by each company varies according to the type of business, as well as the management of the working capital. The working capital management is considered effective if the company is able to balance its sources and the use of working capital (Rita, Wahyudi and Muharam, 2017; Effendi and Disman, 2017).

The company's ability to obtain profits can be seen from the success and ability of companies to use working capital productively. Working capital is the number of funds used to finance the company's operations and to generate income. Each management affects the company's ability to generate profits (profitability). Researches on working capital and profitability had been carried out in some countries and found a positive relationship between the two (Maneerattanarungrot and Donkwa, 2018; Martins and Lopes, 2016; Mun and Jang, 2015; Ukaegbu, 2014). Therefore, the second hypothesis that can be formulated is as follows: 
H2: Working capital has a positive effect on profitability.

Firm size also affects the capital structure. Hirsch and Hartmann (2014) show the theoretical basis on the effect of size on the projection of profit gaining. Large companies with better market access should be able to obtain high profitability. The size of a company can be proxied with the value of the capitalization of its shares in the capital market. Shares with small and large capitalization values have different sensitivity to risk factors which are such important factors to provide asset pricing (Fama and French, 2017; Thalassinos et al., 2015a; Thalassinos and Grima, 2020).

Company size has a positive effect on profitability for large companies tend to have lower profitability and net cash flow volatility (Donelson and Resutek, 2014). The concept of company size is quite widely used to express profitability, which is also supported by empirical studies carried out in developed countries which found a positive relationship (Gaganis, Liu and Pasiouras, 2015; Handriani and Robiyanto, 2019; Sydler, Haefliger and Pruksa, 2014). It was revealed that large companies that use profitability to diversify tend to be able to produce high profitability. Therefore, it can be estimated that large companies tend to have greater profitability than small companies do. Based on this reason, the third hypothesis that can be formulated is as follows:

\section{H3: Firm size has a positive effect on profitability.}

Firm growth is basically influenced by internal and external factors. First, internal factors are defined as factors coming from within the company, including all things that can affect the company's performance and can be regulated and controlled by the company. For example, the decision to increase the company capital and employment and to determine the proportion of retained earnings and the company's strategic actions such as mergers, acquisitions, determination of debt for investment, managerial structures and etc. Second, external factors are factors from outside the company that cannot be controlled by the company itself. For example, raw material prices, competitor behavior, macroeconomic and political conditions, credit interest rates, business climate, and market structure whether it is a monopoly, duopoly, perfect competition, duopsony, and monopsony. If this factor shows a positive sign, it will increase the growth of the company. Researches on firm growth on profitability had been carried out in developed countries and found a positive relationship (Ruangchoengchum, 2017; Zouaghi, Sánchez-García and Hirsch, 2017).

Companies with large investment opportunities indicate that they have bright future prospects, resulting in them to have a positive impact on the value of the company. This is in line with Modigliani and Miller (1958) that the value of the company is more determined by the ability to generate high profitability and investment opportunities. According to the shareholder theory, this profit is used entirely for the benefit of the owner. Increasing profit is a reflection of firm growth. Therefore, the fourth hypothesis that can be formulated is as follows: 
H4: Firm growth has a positive effect on profitability.

Taxes affect the level and combination of company financing sources. This is also the main determinant of project choice and the company's investment objectives. According to Chang, Lee, and Lee (2009), taxes affect capital structure decisions, including debt options, equity, leasing, and other financing instruments that play a role in corporate risk management and influence the form and time of a company's compensation policy. The impact has the potential to reduce company income and tax payments is a very important problem for managers.

According to theoretical postulation, debt has a tax shielding capacity. An example of argument in the trade-off theory is that company managers may reduce the impact of taxes by balancing the level of bankruptcy risk inherent in debt financing with the benefits of shielding taxes arising from it. However, the use of debt depends on access to markets for long-term finance. The extent to which companies can optimize the tax shielding benefits arising from debt use is also determined by the efficiency of the applicable tax system. The relationship between tax and corporate finance is one of the main strategic issues in business management. This is because of the effect of decreasing tax payments on the profitability of the company. As a result, companies tend to make strategic changes in their financing patterns in response to changes in tax rules. The presence of various types of taxes, was also found to be a source of significant imperfection in most capital structure theories.

Beyond the basic assumptions underlying the tax protection hypothesis, there are practical challenges facing companies in an effort to maintain the size and structure of financing patterns. Debt has a tendency to accompany the company to the risk of high bankruptcy. In accordance with the static trade-off theory of capital structure, companies can only borrow to the point where the tax benefits from the additional amount of debt equal to costs. Researches on non-debt tax shields on profitability had been carried out in developed countries and they found a positive relationship (Sardo and Serrasqueiro, 2017; Serrasqueiro and Caetano, 2015; Yazdanfar and Öhman, 2015). Based on this reason, the fifth hypothesis that can be formulated is as follows:

\section{H5: Non-debt tax shields have a negative effect on profitability.}

\section{Data and Research Methods}

The sample of this study was manufacturing firms listed on the Indonesia Stock Exchange from 2010 to 2017. They were chosen based on particular criteria preferred by researchers and they were carefully chosen to make them relevant to the study design. The sample firms had to meet the following requirements: 1) they must be listed on the Indonesia Stock Exchange (IDX) in $2010-2017$; 2) they have a positive asset growth each year from 2010-2017;3) they have financial reports and data for the five years starting from 2010 to 2017. The firms' financial report period 
should also be ended on December $31^{\text {st }}$. Their shares should have a size and book to market value ratio in every December. The data were available in the annual balance sheet of each firm issued in the form of annual reports by IDX.

The type of the variable used in this study consisted of several exogenous variables such as capital structure, working capital, firm size, growth and non-debt tax shield and one endogenous variable which was profitability.

Table 1. Variables

\begin{tabular}{|l|l|l|}
\hline Variable & & Variable Measurement \\
\hline Profitability & Pro & Profit after tax / total asset \\
\hline Capital structure & Cs & Total Debt/Total equity \\
\hline Firm Size & Fz & Natural logarithm of total asset \\
\hline Non debt tax shield & Tx & (EAIT + Depreciation) / average tax rate / total assets \\
\hline Working capital & Wc & Current asset/ Current liabilities \\
\hline Firm Growth & Fg & $\begin{array}{l}\text { (Current year's sales-Last year's sales) / Last year' } \\
\text { sales X 100 }\end{array}$ \\
\hline
\end{tabular}

Source: Authors' compilations.

This study used path analysis with the following regression equation:

Pro $=\beta_{0^{+}}+\beta_{1} \mathrm{Cs}+\beta_{2} \mathrm{Fz}+\beta_{3} \mathrm{Tx}+\beta_{4} \mathrm{Wc}+\beta_{5} \mathrm{Fg}+\varepsilon_{1}$

\section{Results}

The goodness of fit measurements measures the suitability of the observation (covariance or correlation matrix) of the proposed model. In this analysis, the measurements used were first, Chi-Square, and Probability. The Chi-Square value shows the size of the poor fit of a model. If it is 1 , then it indicates that the model has a perfect fit. A significant $p$ value (less than 0.05 ) indicates that the empirical data have differences with established theories, and if the probability value is not significant, it indicates that the empirical data do not fit the model. If the normality assumption is met, it will further result in two types of Chi-Square which are Minimum Fit Function Chi-Square and Normal Theory of Weighted Least Squares Chi-Square. Second, it was the Goodness of Fit Indices (GFI), which is a measure of model accuracy in generating covariance observed matrices. GFI values should range from 0 to 1 , and a GFI value of greater than 0.9 indicates a fit for either model. Third, it was the Adjusted Goodness of Fit Index (AGFI), which is a GFI that has adjusted the influence of degrees of freedom of a model. The AGFI score of 1 shows the perfect fitted model.

Meanwhile, the Parsimony Goodness of Fit Index (PGFI) is the GFI that has adjusted the impact of the degrees of freedom and model complexity. Models are considered to fit well if the PGFI value is much greater than 0.6. Fourth, it was the Root Mean Square Error of Approximation (RMSEA), which measures the deviation 
of parameter values on a model with its population covariance matrix. The RMSEA value of less than 0.05 indicates a fit well model. Confidence intervals to assess the accuracy of RMSEA estimates should be small, indicating that the RMSEA has good accuracy. The test results of goodness of fit of the model using these indicators can be seen in Table 2 as follows:

Table 2. The Test Results of Goodness of Fit Model

\begin{tabular}{|c|c|c|c|}
\hline Measurement & Value & Cut-off value & Conclusion \\
\hline $\begin{array}{l}\text { Chi-Square and Probability: } \\
\text { 1. Minimum Fit Function Chi- } \\
\text { Square } \\
\text { 2. Normal Theory Weighted } \\
\text { Least Square Chi-Square }\end{array}$ & $\begin{array}{l}P=0.25 \\
P=0.33\end{array}$ & $\begin{array}{l}\mathrm{P}>0.005 \\
\mathrm{P}>0.005\end{array}$ & $\begin{array}{l}\text { Fit } \\
\text { Fit }\end{array}$ \\
\hline $\begin{array}{l}\text { The Goodness of Fit Indices } \\
\text { (GFI) }\end{array}$ & 1.03 & $\mathrm{P} \geq 0.90$ & Fit \\
\hline 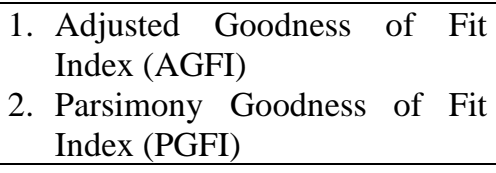 & $\begin{array}{l}0.98 \\
0.89\end{array}$ & $\begin{array}{l}P \geq 0.90 \\
P>0.05\end{array}$ & $\begin{array}{l}\text { Fit } \\
\text { Fit }\end{array}$ \\
\hline $\begin{array}{l}\text { 1. Root Mean Square Error of } \\
\text { Approximation (RMSEA) } \\
\text { 2. P-Value for Test of Close Fit } \\
\text { (RMSEA) }\end{array}$ & $\begin{array}{l}0.002 \\
0.001 \\
\end{array}$ & $\begin{array}{l}<0.050 \\
<0.050\end{array}$ & $\begin{array}{l}\text { Fit } \\
\text { Fit }\end{array}$ \\
\hline $\begin{array}{l}\text { 1.Expected Cross Validation } \\
\text { Index (ECVI) } \\
\text { 2. ECVI for Saturated Model } \\
\text { 3. ECVI for Independence Model }\end{array}$ & $\begin{array}{l}0.23 \\
0.27 \\
2.78\end{array}$ & 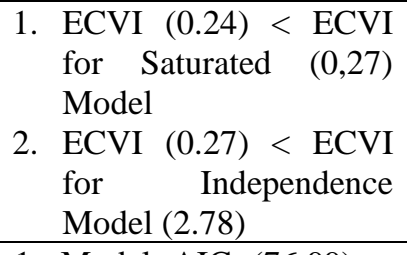 & Fit \\
\hline $\begin{array}{l}\text { Akaike's Information Criterion } \\
\text { (AIC) and CAIC: } \\
\text { 1. Model AIC } \\
\text { 2. Independence AIC } \\
\text { 3. Saturated AIC } \\
\text { 4. Model CAIC } \\
\text { 5. Independence CAIC } \\
\text { 6. Saturated AIC }\end{array}$ & $\begin{array}{l}76.99 \\
584.11 \\
90.00 \\
221.59 \\
984.11 \\
311.35\end{array}$ & $\begin{array}{l}\text { 1. Model AIC }(76.99)< \\
\text { Independence AIC } \\
(584.11) \text { and Model } \\
\text { AIC (221.59) < } \\
\text { Saturated AIC }(311.35) \\
\text { 2. Model CAIC }(76.99)< \\
\text { Independence }(984.11) \\
\text { and Model CAIC } \\
(221.59)<\text { Saturated } \\
\text { AIC }(311.35)\end{array}$ & Fit \\
\hline $\begin{array}{l}\text { Fit Index: Normed Fit Index } \\
\text { (NFI) Comparative Fit Index } \\
\text { (CFI) Incremental Fit Index (IFI) } \\
\text { Relative Fit Index (RFI) } \\
\end{array}$ & $\begin{array}{l}P>0.95 \\
P>0.95 \\
P>0.95 \\
P>0.95\end{array}$ & $\begin{array}{l}0.99 \\
0.98 \\
0.99 \\
0.97\end{array}$ & $\begin{array}{l}\text { Fit } \\
\text { Fit } \\
\text { Fit } \\
\text { Fit }\end{array}$ \\
\hline
\end{tabular}

Source: Results of data processing by LISREL

Fifth, it was the Expected Cross Validation Index (ECVI), which is used to assess the trend that models on a single sample can be cross-validated if the sample size and population are equal. If the ECVI value of the model is lower than the ECVI 
value of the saturated model and independence model, it indicates that the model is fitted well. Sixth, it was the Akaike's Information Criterion (AIC) and CAIC, which were used to assess the Parsimony problem in the fitted model assessment. If the AIC and CAIC values are lower than the AIC of the saturated model and independence model, it means that it has a better fitted model. Seventh, it was the Normed Fit Index (NFI) and Comparative Fit Index (CFI), which were used to determine the model fitness. The NFI and CFI values range between 0 and 1. A model is said to be fitted well if the NFI and CFI values are greater than 0.9. NonNormed Fit Index (NNFI) was used to overcome problems arising from model complexity. Incremental Fit Index (IFI) was used to address Parsimony problems and sample sizes and associated with the NFI. The cut-off limit of IFI is 0.9 . Meanwhile, the Relative Fix Index (RFI) was then used to measure fitness, whose value ranges between 0 and 1 if the greater value indicates superior fit. Table 2 shows that the model was fitted well.

A path analysis was done on the profitability, firm size, non-debt tax shield, working capital, and firm growth variables. The next step was to test the hypotheses proposed. The result can be seen from the t-value on Table 3:

Table 3. Direct Effect of Profitability, Capital Structure, Firm Size, Non-Debt Tax Shield, Working Capital, and Firm Growth

\begin{tabular}{|l|l|l|l|}
\hline Variables & Unstandardized Estimate & $\begin{array}{l}\text { Standardized } \\
\text { Coefficient }\end{array}$ & t-value \\
\hline $\mathrm{Cs} \rightarrow$ Pro & 0.27 & 0.07 & $-1.99^{*}$ \\
\hline $\mathrm{Fz} \rightarrow$ Pro & 0.14 & 0.03 & $2.78^{*}$ \\
\hline $\mathrm{Tx} \rightarrow$ Pro & 0.13 & 0.60 & -1.26 \\
\hline $\mathrm{Wc} \rightarrow$ Pro & 0.61 & 0.58 & $2.05^{*}$ \\
\hline $\mathrm{Fg} \rightarrow$ Pro & 0.40 & 0.50 & $2.07^{*}$ \\
\hline
\end{tabular}

Source: Results of data processing by LISREL

Note: *) significant on $\alpha=5 \%$

\section{Discussion}

The first hypothesis which states that capital structure has a positive effect on profitability is not supported empirically. This is indicated by the t-value of -1.99 which is significant at $\alpha=5 \%$. This shows that capital structure is negatively related to profitability. This finding provides empirical evidence that the existence of the pecking order indicates that the company would initially rely on internal funds, i.e. undistributed profits, where there was no asymmetry information. Then, they would turn to debt if additional funds were needed and they eventually would issue equity to cover the remaining capital needs. However, if the debt used by the company exceeded $45 \%$ of the total assets, the company was in an unhealthy condition to gain profitability. The results of this study are in line with the researches by Kodongo, Mokoaleli-Mokoteli and Maina (2015). 
The second hypothesis states that working capital has a positive effect on company 's profitability. The results of this study indicate that this second hypothesis is supported empirically because the t-value is 2.78 which is significant at $\alpha=5 \%$. Working capital had a contribution to affect the profitability, it was one aspect that must be considered by the company. If the company could not maintain a satisfactory working capital, then the company would likely be in an insolvent state. Current assets must be large enough to cover the current debt so as to illustrate a satisfactory margin of safety. The results of this study are in line with the study conducted by Afrifa (2016).

The third hypothesis states that firm size has a positive effect on profitability. The results of this study indicate that it is not supported empirically, because the t-value is only 1.26 , which is also not significant at $\alpha=5 \%$ not even at $\alpha=10 \%$. Large companies tended to have higher income volatility and net cash flow. Large companies that could achieve maximum profitability to diversify tended to utilize the investment capacity to obtain high profitability. Therefore, it could be estimated that large companies tended to have greater investment than small companies. Thus, the ability to obtain profitability was also different. The results of this study are in line with the research that has been done by Mun and Jang (2015) and Vithessonthi and Tongurai (2015).

The fourth hypothesis test states that firm growth has a positive effect on profitability. The results indicate that it is supported empirically because the t-value is 2.78 and is significant at $\alpha=5 \%$. Growing companies also had high investment opportunities which could be obtained if they had a project with a positive net present value as a signal to grow in the future. The results of this study are in line with the research conducted by Handriani and Robiyanto (2019), Nason and Wiklund (2018).

The fifth hypothesis states that non-debt tax shields have a negative effect on profitability. The results show that it is not supported empirically because of the tvalue which is only -1.26 and is not significant at $\alpha=5 \%$, not even at $\alpha=10 \%$. These findings are in line with the researches conducted by Abel (2018) and Serrasqueiro and Caetano (2015).

\section{Conclusions and Recommendations}

This study aims to examine the profitability determinants of manufacturing firms in Indonesia. The results show that working capital, firm size and firm growth were positively related to profitability. Furthermore, this study also found that capital structure and non-debt tax shields did not affect profitability. This is consistent with the pecking order and financial agency theory which helps in understanding the application of corporate value studies for companies in Indonesia. This study was able to explore the profitability determinants of Indonesian manufacturing companies where more detailed evaluations could be carried out. Furthermore, 
empirical findings will help company managers to make decisions in relation to the efforts to improve the company's profitability.

This study implies that managers need to adjust their investment needs with the profitability that has been achieved and the total assets of the company and to maximize the value of the company by managing current assets so that the rate of the return on marginal investment is equal to or greater than the cost of capital used to finance the current assets. Furthermore, financial managers must be able to determine essential investment objectives by maximizing the use of assets and fixed assets which are expected to make the company to enjoy the sales growth in the future.

\section{References:}

Abel, A.B. 2018. Optimal Debt and Profitability in the Trade-Off Theory. The Journal of Finance, 73(1), 95-143. doi:10.1111/jofi.12590.

Afrifa, A.G. 2016. Net Working Capital, Cash Flow and Performance of UK SMEs. Review of Accounting and Finance, 15(1), 1-35.

Aqil, M., Ahmed, R., Vveinhardt, J., Streimikiene, D. 2019. Factors Influencing the Profitability of Heavy Vehicle Industry: A Case of Pakistan. Montenegrin Journal of Economics, 15(1), 61-72. doi:https://doi.org/10.14254/1800-5845/2019.15-1.5.

Balios, D., Daskalakis, N., Eriotis, N., Vasiliou, D., McMillan, D. 2016. SMEs capital structure determinants during severe economic crisis: The case of Greece. Cogent Economics \& Finance, 4(1). doi:10.1080/23322039.2016.1145535.

Battaglia, F., Gallo, A. 2015. Risk governance and Asian bank performance: An empirical investigation over the financial crisis. Emerging Markets Review, 25, 53-68. doi:10.1016/j.ememar.2015.04.004.

Borio, C., Gambacorta, L., Hofmann, B. 2017. The influence of monetary policy on bank profitability. International Finance, 20(1), 48-63. doi:10.1111/infi.12104.

Bratamanggala, R. 2018. Factors Affecting Earning Per Share: The Case of Indonesia. International Journal of Economics and Business Administration, 6(2), 92-100.

Chang, C., Lee, A.C., Lee, C.F. 2009. Determinants of capital structure choice: A structural equation modeling approach. The Quarterly Review of Economics and Finance, 49(2), 197-213. doi:10.1016/j.qref.2008.03.004.

Donelson, D.C., Resutek, R.J. 2014. The predictive qualities of earnings volatility and earnings uncertainty. Review of Accounting Studies, 20(1), 470-500. doi:10.1007/s11142-014-9308-5.

Effendi, A.K., Disman, D. 2017. Liquidity Risk: Comparison between Islamic and Conventional Banking. European Research Studies Journal, 20(2A), 308-318.

Fama, E.F., French, K.R. 2017. International tests of a five-factor asset pricing model. Journal of Financial Economics, 123(3), 441-463. doi:10.1016/j.jfineco.2016.11.004.

Gaganis, C., Liu, L., Pasiouras, F. 2015. Regulations, profitability, and risk-adjusted returns of European insurers: An empirical investigation. Journal of Financial Stability, 18, 55-77. doi:10.1016/j.jfs.2015.03.001.

Handriani, E., Robiyanto, R. 2018a. Corporate finance and firm value in the Indonesian manufacturing companies. International Research Journal of Business Studies, 11(2), 113-127. doi:https://doi.org/10.21632/irjbs.11.2.113-127. 
Handriani, E., Robiyanto, R. 2018b. Investment opportunity and industrial growth in Indonesia. International Journal of Business and Society, 19(2), 295-312.

Handriani, E., Robiyanto, R. 2019. Institutional ownership, independent board, board size, and firm performance: Evidence from Indonesia. Contaduría y Administración, 64(3), 1-16. doi:http://dx.doi.org/10.22201/fca.24488410e.2018.1849.

Hasbi, H. 2015. Islamic Microfinance Institution: The Capital Structure, Growth, Performance and Value of Firm in Indonesia. Procedia - Social and Behavioral Sciences, 211, 1073-1080. doi:10.1016/j.sbspro.2015.11.143.

Hirsch, S., Hartmann, M. 2014. Persistence of firm-level profitability in the European dairy processing industry. Agricultural Economics, 45(S1), 53-63. doi:10.1111/agec.12129.

Kodongo, O., Mokoaleli-Mokoteli, T., Maina, L.N. 2015. Capital structure, profitability and firm value: panel evidence of listed firms in Kenya. African Finance Journal, 17(1), $1-20$.

Maneerattanarungrot, C., Donkwa, K. 2018. Capital structure affecting firm value in Thailand. ABAC Journal, 38(2), 133-146.

Martins, M.M., Lopes, I.T. 2016. Intellectual capital and profitability: A firm value approach in the European companies. Verslas: teorija ir praktika, 17(3), 234-242. doi:10.3846/btp.2016.673.

Mateev, M., Poutziouris, P., Ivanov, K. 2013. On the determinants of SME capital structure in Central and Eastern Europe: A dynamic panel analysis. Research in International Business and Finance, 27(1), 28-51. doi:10.1016/j.ribaf.2012.05.002.

Miller, M.H., Modigliani, F. 1961. Dividend Policy, Growth, and the Valuation of Shares. Journal of Business, 34, 411-433.

Modigliani, F., Miller, M.H. 1958. The Cost of Capital, Corporation Finance and the Theory of Investment. American Economic Review, 48(13), 261-297.

Mun, S.G., Jang, S.S. 2015. Working capital, cash holding, and profitability of restaurant firms. International Journal of Hospitality Management, 48, 1-11. doi:https://doi.org/10.1016/j.ijhm.2015.04.003.

Nason, R.S., Wiklund, J. 2018. An assessment of resource-based theorizing on firm growth and suggestions for the future. Journal of Management, 44(1), 32-60. doi:https://doi.org/10.1177\%2F0149206315610635.

Rita, M.R., Wahyudi, S., Muharam, H. 2017. The dynamics of female entrepreneurs in fulfilling their financial needs: Demand side entrepreneurial finance perspective of small and medium-sized entreprises. Journal of Applied Economic Sciences, 12(8), 2351-2367.

Ruangchoengchum, P. 2017. Performance Measurement that Affects SMEs Business Profits: Case Study of SMEs in Khon Kaen Province. ABAC Journal, 37(1), 26-42.

Rupeika-Apoga, R., Zaidi, H.S., Thalassinos, E.Y., Thalassinos, I.E. 2018. Bank Stability: The Case of Nordic and Non-Nordic Banks in Latvia. International Journal of Economics and Business Administration, 6(2), 39-55. DOI: 10.35808/ijeba/156.

Sardo, F., Serrasqueiro, Z. 2017. A European empirical study of the relationship between firms' intellectual capital, financial performance and market value. Journal of Intellectual Capital, 18(4), 771-788.

Serrasqueiro, Z., Caetano, A. 2015. Trade-Off Theory versus Pecking Order Theory: capital structure decisions in a peripheral region of Portugal. Journal of Business Economics and Management, 16(2), 445-466. doi:https://doi.org/10.3846/16111699.2012.744344. 
Sutomo, S., Wahyudi, S., Rini Demi Pangestuti, I., Muharam, H. 2019. Determinants of financing decision: empirical evidence on manufacturing firms in Indonesia. Investment Management and Financial Innovations, 16(2), 159-170. doi:10.21511/imfi.16(2).2019.14.

Sydler, R., Haefliger, S., Pruksa, R. 2014. Measuring intellectual capital with financial figures: Can we predict firm profitability? European Management Journal, 32(2), 244-259. doi:10.1016/j.emj.2013.01.008.

Thalassinos, I.E., Ugurlu, E. and Muratoglu, Y. 2015a. Comparison of Forecasting Volatility in the Czech Republic Stock Market. Applied Economics and Finance, 2(1), 11-18. DOI: 10.11114/aef.v2i1.608.

Thalassinos, I.E., Thalassinos, E.P., Venedictova, B., Yordanov, V. 2015b. Currency Board Arrangement Capital Structure Macro-Financial Diagnostic. SSRN-id2624333.pdf.

Thalassinos, I.E., Grima, S. 2020. Financial Derivatives: A Blessing or a Curse? Emerald Publishing Co., London UK, ISBN: 9781789732467.

https://books.emeraldinsight.com/page/detail/FinancialDerivatives/?k=9781789732467.

Ukaegbu, B. 2014. The significance of working capital management in determining firm profitability: Evidence from developing economies in Africa. Research in International Business and Finance, 31, 1-16.

Utama, C.A., Sulistika, M. 2015. Determinants of Investment Opportunity Set (Degree of Internationalization and Macroeconomic Variables). Gadjah Mada International Journal of Business, 17(2), 107-124. doi:10.22146/gamaijb.6905.

Vithessonthi, C., Tongurai, J. 2015. The effect of firm size on the leverage-performance relationship during the financial crisis of 2007-2009. Journal of Multinational Financial Management, 29, 1-29. doi:https://dx.doi.org/10.2139/ssrn.2285980.

Wahyudi, S., Goklas, F., Rita, M.R., Hersugondo, H., Laksana, R.D. 2019. The Determinants of Corporate Hedging Policy: A Case Study from Indonesia. International Journal of Economics and Business Administration, 7(1), 113-129.

Yazdanfar, D., Öhman, P. 2015. Debt financing and firm performance: an empirical study based on Swedish data. Journal of Risk Finance, 16(1), 102-118.

Zouaghi, F., Sánchez-García, M., Hirsch, S. 2017. What drives firm profitability? A multilevel approach to the Spanish agri-food sector. Spanish Journal of Agricultural Research, 15(3), 1-15. 